Check for updates

London

Cite this as: $B M J 2022 ; 376: 0469$ http://dx.doi.org/10.1136/bmj.0469 Published: 22 February 2022

\title{
Covid-19: Scientists and medics warn that it is too soon to lift all restrictions in England
}

Matthew Limb

The UK government has announced an end to all covid-19 restrictions in England, saying that vaccines and treatments will be the "first line of defence" from now on.

Most of the public will lose access to free tests, and people who become infected with SARS-CoV-2 will no longer be legally required to self isolate, under a "Living with covid" strategy that is designed to shift the focus from government interventions to personal responsibility. ${ }^{1}$

But the measures unveiled to MPs by the prime minister on 21 February drew criticism from opposition parties, scientists, and medical leaders, despite some acceptance of the case for rebalancing covid protections and lowering costs.

Some experts warned that numbers of omicron cases were still too high to lift restrictions, with a risk of further spread of the virus and insufficient support for certain groups of vulnerable people.

There has also been concern that stopping self-isolation support payments to people on lower incomes will widen inequalities, while the BMA and the NHS Confederation have called for the continuation of free covid tests for healthcare workers to protect staff and patients.

Trish Greenhalgh, professor of primary care health sciences at the University of Oxford, said that ending isolation and free testing in England was a "huge mistake" and called on the government to publish the scientific reasoning for its decisions.

More than 3360 scientists and doctors have signed an open letter to England's chief medical officer, Chris Whitty, and the UK's chief scientific adviser, Patrick Vallance, asking them to clarify the evidence for the government's decisions. ${ }^{2}$ They said that the policy was "almost certain to increase the circulation of the virus and remove the visibility of emerging variants of concern."

They warned, "We have no reason to assume that all future new variants will be mild.” They pointed to documents from the Scientific Advisory Group for Emergencies (SAGE) and its Scientific Pandemic Influenza Group on Modelling (Operational) subgroup (SPI-M-O), in which advisers warned of increased virus transmission if self-isolation and testing were removed, with a potential for transmission to "increase by between around $25 \%$ to $80 \%$ if the population were to return to pre-pandemic behaviours and no mitigations."

\section{Sick pay}

David Finch, assistant director of healthy lives at the Health Foundation, said that expecting people to take personal responsibility to reduce the spread of the coronavirus ignored the fact that insufficient coverage of sick pay would drive many people to go to work while infected. "The strategy fails to recognise and make provisions for the unequal impact that covid-19 has had across society so far and the unequal risks from 'living with covid,"” he said.

From 24 February people will no longer need to self-isolate if they have covid or believe they do, although they will still be advised to stay at home and avoid contact with other people for at least five full days. Self-isolation support payments will stop, although covid provisions for statutory sick pay can still be claimed for a further month.

After 1 April it is up to people with covid symptoms to decide whether to stay at home, exercising personal responsibility, "just as we encourage people who may have flu to be considerate to others," Boris Johnson said.

Routine contact tracing will end so 24 February, so fully vaccinated close contacts and those under 18 will no longer be legally required to test daily for seven days.

From 1 April free mass symptomatic and asymptomatic testing for the general public will end. Johnson said that the government would continue to provide free tests to the most elderly and most vulnerable people with symptoms and to social care staff. "We're working with retailers to ensure that everyone who wants to can buy a test," he said.

Johnson said that the measures were possible because of the success of the vaccination programme, the passing of the omicron wave-with the number of people in hospital with covid in England now under 10000 and falling - and the link between infection and severe disease now "substantially weakened."

He said, "Together with the treatments and scientific understanding of the virus that we've built up we now have sufficient levels of immunity to complete the transition from protecting people with government interventions to relying on vaccines and treatments as our first line of defence."

He said the test, trace, and isolate regime was costing $€ 15.7 \mathrm{bn}$ in the latest financial year and must be scaled back, although the government would be able to ramp up testing if necessary.

However, divisions appeared between Johnson and his advisers. Whitty emphasised the need to maintain public health measures-to isolate, ventilate, wash hands, and wear masks in enclosed spaces, because cases remained high-while Vallance said that he would have preferred case numbers to be lower before all restrictions were lifted. 


\section{Two tier system}

Chaand Nagpaul, the BMA's chair of council, said that the government's strategy would create a two tier system, where people who could afford to pay for testing and to self-isolate would do so, while others would be "forced to gamble on the health of themselves and others."

He said, "Providing free tests to clinically vulnerable people-and only once they develop symptoms and are potentially very unwell-but not providing any free tests to friends or family who come into contact with them is completely illogical, as the priority should be protecting them from infection in the first place.

"The same goes for care home staff, who will only be tested if they have symptoms, by which time they could have passed on the virus to vulnerable residents."

Despite prior media reports that the Office for National Statistics' infection survey might be discontinued, Johnson said it would be retained, allowing detailed tracking of a virus that had "not gone away" and the ability to spot surges "as and where they happen." However, no details were given of the format the survey would take in the future.

The Health Foundation said that limits to free testing could lead to infection rates increasing more rapidly in poorer communities where the impact of infection may be more severe, given the lower uptake of vaccines in more deprived areas of the country.

Chris Hopson, chief executive of NHS Providers, said that the government's scientific advice should be made public as quickly as possible. He said, "There are many in the NHS who are concerned about the potential impact of these decisions. It's therefore vital that the government should keep an open mind and be ready, for example, to restore those elements of the testing and surveillance regimes should they be needed."

\section{Devolved nations}

The leader of the Scottish National Party, Ian Blackford, told MPs that Johnson's strategy was "bereft of science" and lacked any serious engagement with the devolved nations of the UK. Scotland's first minister, Nicola Sturgeon, indicated that there was likely to be a move to "more targeted testing" in the next few months, while saying that isolation "still has a part to play." Currently, people with symptoms of covid-19 in Scotland are advised to isolate and book a PCR test, and that advice has not changed.

The Department of Health in Northern Ireland said it will consider the Living with Covid Plan and its implications. Health minister Robin Swann emphasised the importance of a cautious approach, given the continuing high numbers of daily infections and pressure on hospitals.

In Wales legal protections relating to self-isolation and face coverings remain in place, while other legal protections are being kept under review.

1 Government HM. Covid-19 response: living with covid-19. Feb 2022. https://assets.publishing.service.gov.uk/government/uploads/system/uploads/attachment_data/file/1056229/COVID19_Response_-_Living_with_COVID-19.pdf.

2 Open letter from UK scientists and medics re: early end to England's isolation rules. Feb 2022. https://openletter.earth/open-letter-from-uk-scientists-and-medics-re early-end-to-englands-isolation-rules-14a731a1. 